\title{
The exploration of a sense of belonging: An explanation of Naipaul's novel half a life \& magic seeds
}

\author{
Yurong Wang, Li Lin \\ Department of English, College of Foreign Languages, China Three Gorges University, Yichang, China
}

Email address:

1058940294@qq.com (Yurong Wang),786343846@qq.com (Li Lin)

\section{To cite this article:}

Yurong Wang, Li Lin. The Exploration of a Sense of Belonging: An Explanation of Naipaul's Novel Half a Life \& Magic Seeds. International Journal of Literature and Arts. Vol. 2, No. 5, 2014, pp. 187-191. doi: 10.11648/j.ijla.20140205.16

\begin{abstract}
V. S. Naipaul is a Trinidad-born Nobel Prize-winning British writer known for his comic early novels set in Trinidad. This famous post-colonial writer, V. S. Naipaul, has been paying close attention to the social reality and life in post-colonial society. In 2001, his novel Half a Life won the booker prize; It tells the story about Willie Chandran's first 18 years' life. However, it is not a complete story; it is a precursor to Naipaul's novel Magic Seeds. In 2004, Naipaul completed the story by his novel Magic Seeds. Seeking for a sense of belonging is the theme throughout the whole process in this two books. In his last novel Magic Seeds, this theme has got a full explanation. Through an interpretation of these two books about Willie's life, this paper aims to explore the protagonist---Willie's life process in seeking his sense of belonging and the reason for its missing. Willie is only one of the representatives among the diasporas who try their best to claim for their identity and a sense of belonging. So at the same time, it aims to reveal the theme and relate to the contemporary situation to interpret the realistic significance of the importance of a sense of belonging. Literature is the reflection of our society, its development and change, however subtle it is, this is also true of Naipaul's two famous novels. They shed lots of light on our daily life and heart.
\end{abstract}

Keywords: V. S. Naipaul, Half a Life, Magic Seeds, A Sense of Belonging, Missing, Realistic Significance

\section{Introduction}

Vidiadhar Surajprasad Naipaul, as one of the most excellent writers in contemporary Britain, had won the honorable Booker Prize in 1971 and Nobel Prize in Literature in the year 2001. He is also an outstanding novelist of Indian ancestry. The Swedish Academy praised him for "having united perspective narrative and incorruptible scrutiny in works that compel us to see the presence of suppressed histories (Naipaul, 2001)". This is the best affirmation for the literature-lover---Naipaul, who is a "marginal man" to some extent. Pritchett once said that Naipaul is the most excellent British writer in nowadays. Naipaul was born in Trinidad and grew up in the cultural environment full of Indian atmosphere, then after his graduation from Oxford University; he became a member of Britain. In this sense, he is a post-colonial writer with complicated status. According to Kong Cao (2000: 163), his complicated life experiences and multicultural background leads to the loss of his own national identity, leads to the lack of self-recognition in cultural aspect and also a sense of belonging. As literature is the mirror of social reality, this is also true of Naipaul's literature works. His works are either closely connected with his real life experience, or served as his autobiography which reflects his shadow. In this respect, the theme of exploring a sense of belonging runs through the whole process of his writing. In his famous book Half a Life published in 2001 and Magic Seeds published in 2005, the theme had also been manifested profoundly. Half a Life tells the story about Willie's 18-year lifetime and Magic Seeds is the sequel of his book Half a Life published in 2001. It tells such a story: the male protagonist Willie lost his home, in order to seek for his sense of belonging, he went to England, Africa, Berlin and then returned to India and England. His trace formed a circle, and unfortunately, he still went back to the starting point without finding his sense of belonging. In the last century, the famous psychologist Abraham Maslow (1943) proposed the Hierarchy of Needs Theory, which includes the need of a sense of belonging. Belongingness is of vital importance in people's daily life, not only Willie but 
also we are exploring it constantly. In this way, the paper aims to analyze the reason for the loss of belongingness in this novel and associate it with our practical life, so as to explore the author's understanding of life.

\section{Literature Review}

\subsection{A Brief Introduction of the Novel Half a Life}

Half a Life is set in India, Africa and Europe, to be more specifically, in London, Berlin and Portugal. It tells the story about Willie's first eighteen years. Willie has a Brahmin father and a Dalit mother. His father Sunderland was born in the highest caste of India: Brahmin. In response to Gandhi's call, he married a woman at lower caste. In the book, it tells about the origin of Willie's name. His middle name was given by his father as a homage to the English writer Somerset Maugham.

He had visited his father in the temple where the father was living under a vow of silence. Willie's grandfather was a secretary of the government, however, his father stayed in a temple for silence. Willie looked down upon his father and thought him escaping from the reality. He leaves India to go to London to study. He was eager just "to get away from what he knew" (Naipaul, 2001). He wrote a book and was able to publish it, but it's not a success. With his scholarship came to an end, he had no plan for his future. So, he married with Anna, a girl he wasn't truly love, just to find somewhere to live. He went to Africa, only to find that it didn't belong to him. Without finding a suitable job, he stayed there for eighteen years depending on Anna. Then, he went to Berlin, where his sister Sarojini lived. Half a Life is a novel of incompleteness. In the Guardian, Paul Theroux commented that "the novel ends nowhere. It is about nothing, just an assortment of Naipaul's situations and remarks. Anyone who does not know his work will find it clumsy, unbelievable, badly written, willful and weird. I do, too, but it is calculatedly weird and clumsy. Every unsatisfactory bit of the book is deliberate -- the odd structure, the implausible situations, the stilted dialogue, the harsh tone, the apparent clichés" (2001). However, It is not a novel of incompleteness actually. His novel Magic Seeds is a sequel of Half a Life.

\subsection{A Brief Introduction of the Novel Magic Seeds}

Magic Seeds is set in India and Europe, specifically in Berlin and London. It began with where Half a Life left off. Willie lived with his sister Sarojini in west Berlin. He had nothing to do there and just lived on his sister. He followed Sarojini's persuasion to join an underground movement. $\mathrm{He}$ became involved with communist guerrillas, but without any real sense of commitment to the rebel cause. He was very clear about the shortcomings and wrong-advised tactics of the underground movement. However, he still remained there partly because of inertia and partly of fear that he would be killed by former comrades. Later, he tried to run away with a friend, but it didn't work and he was imprisoned.
His English friend Roger arranged to republish his collection of stories, so he got released. There, he seemed to be in the upper-middle class. He had some relationship with English women, but he was still abandoned by them. He could't find a sense of belonging and felt that he was left by the whole world. Magic seeds stand for hope. Even in his life years, if he can find his real self, there is still hope.

\section{Reasons of the Lack of a Sense of Belonging}

According to Maslow's Hierarchy of Needs (1943), needs consist of physiological needs, safety needs, love and belonging (or social needs), esteem and self-actualization. Love and belongingness needs are at the third stage after physiological needs and safety needs. If one can not meet this need, his/her self-actualization needs cannot be satisfied. It is very important to get a sense of belonging. Willie pursue it through his lifetime without a success. In the following parts, we will discuss the reasons of the lack of a sense of belonging through his two novels, Half a Life and Magic Seeds.

\subsection{The Lack of a Sense of Belonging: The Loss of "Root"}

Human beings form as a social group with thoughts and emotions, for example, a country, nation, tribe, army, class, group, school, family and so on. People live in different social communities, among which connections and conflicts are closely interwined with each other; so people has a mental orientation for the social community they firstly belongs to. This mental orientation, according to psychologist, is called a sense of belonging. Form this analysis, we can find that the origin of a sense of belonging is mostly influenced by the society.

For Naipaul himself, he is a writer with complicated status. He was born in Trinidad and grew up in the cultural environment full of Indian atmosphere, then after his graduation from Oxford University, he became a member of Britain with the education of English culture. These two totally different social environments influenced Naipaul's life, in this sense, his life is a multicultural one interwined with Indian culture and English culture. While it is this multicultural background that leads to his loss of national identity and his sense of belonging. As a matter of fact, he has been trying to integrate into English society and be a part of the colony, however, the arrival is a mystery forever (Wang Shalie, 2010: 7). According to Edward Said: "there is a in-between state of exile. They neither integrate into the new environment, nor do they separate from the old environment; they are trapped into this in-between confusion. On the one hand, they are homesick for the old environment; on the other hand, they are a imitator and tramp in the new environment" (2002). So, Naipaul is a such kind of exile. According to Mei Xiaoyun: "Naipaul is rootless in culture, because he is separated from his motherland---India and he cannot truly arrive England 
floating out of European culture. He cannot find a belonging for his soul, which add to his rootless. He is an exile in spirit, a tramp of India, an outsider of England, a foundling of Trinidad and a world citizen in this global era, so he cannot find his root" (2003: 4). As a writer and intellectual from the third world, he gives great concern and deep thinking about the society, history, politics and culture of the third world in his books (Gao Zhaocheng, 2005: 94). Half a Life and Magic Seeds are such kind of books. It associates with the places Naipaul lives together.

Very similar to Naipaul's experience, in this novel, the protagonist Willie was born in India and grew up in Indian culture; he went to England for university study at the age of 20; after graduation, he married with Anna and stayed in Africa for eighteen years. However, later, he began to realize that this was not the place he wanted to stay and this was not the life he wanted to live either, more specifically, it was Anna's life. Then, he left his wife and went to west Berlin in which his sister lived, later his sister persuaded him to go back to India to take part in the underground movement. He went to India and had a miserable life there and lost himself, after the failure of the movement, he went back to England. From this description, we can see that Willie's life experience is almost an autobiography of the author Naipaul. The multicultural background of Naipaul leads to the result that he lacks self-recognition and s sense of belonging at the level of culture; he no longer miss his hometown and is willing to wander about in order to find his "spiritual home in his imagination" (Kong Cao, 2000: 17). Just as in the beginning of the book, Willie said: "I don't see what I can do. I don't know what I can go" (Naipaul, 2005: 5); "I am always an outsider, now as well; I am in Berlin, but what can I do" (ibid: 8). Willie was homeless and had nothing to do. He wanted to integrate into the local society, but he was confused by his "root"---Indian culture. Willie's mind, half philosophical and half innocent, express the author Naipaul's anxiety; Willie's story and traveling experience, reflects Naipaul's intention and thoughts of rebuilding a world (Xu Zhiqiang, 2008: 97). However, this is not enough. It also conveys the mental states and struggle of a large number of immigrants with a multicultural background. When standing under a stable cultural background, people will not pay much attention to the differences, but to pay their attention to thinking at the spiritual level. However, in the process of immigration, the alienation between immigrants and their original culture break the stability of the cultural construction, in this way, going through different cultures leads to a crisis of lacking a sense of belonging. People can cross the boarder of countries, but they cannot gain belongingness. That is why immigrants always stay in malposition. As to Homi Bhabha's theory (2004), they live in "hybrid culture". Thus, as an immigrant writer, Naipaul cannot get rid of this confusion as well, and a lot of thinking by Willie in Magic Seeds is the best presentation. Because of the influence of the environment, immigrants stay in an in-between state, neither integrate into the new environment outright, nor separate from the new environment, so this result in the lack of a sense of belonging. Just as Willie said in the novel: "someone, not just myself, lying in the corner and now crawl out. I don't know whether I can get along well with this new man. I don't know I can get rid of it or not I think he will always be there, waiting for me" (Naipaul, 2005: 173). From these bitter words, we can see that, the loss of a sense of belonging has a great impact on people's spiritual world and life.

\subsection{The Lack of a Sense of Belonging: The Loss of "Home"}

In the novels Half a Life and Magic Seeds, the description of bus station, dock, airport, hotel and camp etc. is of high frequency, which present an image of a homeless exile. Willie said: "it's the one thing I have worked all my life: not being at home anywhere, but looking at home" (Ibid: 74). But for him, there is not a home always. He was eager to own a house belongs to him, a bed belongs to him, and this was the reason why every time Willie went to a place, he gave a close observation and description of the house in the novel Magic Seeds. In the novel, he described weavers' houses, house of the police station, and gatherings of the railway workers. To Willie, a house is not only a shelter from the wind and rain, it's more like a place to live and a symbol of his dignity. So whether he has a house of his own or lie in his own bed becomes his major concern. House, here, is the symbol of a sense of belonging of an individual. The lack of a sense of belonging, to a great extent, is result from the loss of home. When a baby is born, he/she belongs to a family firstly. So, home, as the smallest group unit in the society, is the first place that people can have a sense of belonging. Research statistics show that the determinant of happiness index is family happiness index. Willie's father Sunderland was born in the highest caste in India---Brahmin. In response to Gandhi's call, he married a lower caste wife. Philosophers think that the image of mother is the image of soul, but to Willie, his mother, born in a low caste, is foolish and backward. From his former novel Half a Life, he is sarcastic about his mother. He thought that he was born incomplete and a half-blooded "hybrid", so he hated his mother. Very likely, because of the lack of mother's love, he lacks a sense of belonging deep down, so he spends his whole life pursuing for it. At the same time, he looks down upon his father as well. Willie's grandfather works as a secretary for the government, but Willie's father stays in the temple as a priest and lives a quiet life. His father thought it as a life that the God of destiny gives to him, while Willie thought it as a kind of escape. Based on this reason, he looks down upon his father. He didn't want to live a life whether like his grandfather's or his father's. In this respect, he went abroad to get rid of it, however, it didn't work. India, to Willie, just as Naipaul has said: "it's not my home and it can't be" (Naipaul: 2005: 3). Willie had a resistance of his home when he was young, so the feeling of home didn't take root in his heart; the lack of parents' love resulted in the loss of home, and thereafter, the loss of a sense of belonging. He spent his whole life pursuing this belongingness. Until later, Willie 
realized that he misunderstood his father. "I thought that because he was a Brahmin, so he lived easily in this world. He wasted his time and idled away his life, he was a liar. But now I begin to realize that he must be very difficult" (ibid: 49). However, it's to late for him to know that. His sister Sarojini is another relative to him. The first chapter of Magic Seeds is mostly the dialogue between them. Sarojini persuaded him to take part in underground movement, and later he found it a wrong decision. It seems that Willie lives his life according to other people's suggestions. He never plan his life and think about how to live, which makes the matter worse. Home is the harbor of our soul and the residence of out heart; we can truly feel a strong sense of belonging at home, forget the worldly competition and be the purist one (Wang Yurong, 2013: 30). In this regard, the lack of a sense of belonging also result from the loss of home.

\subsection{The Lack of a Sense of Belonging: The Loss of "Love"}

After Willie left India, he went to England for university study. The most important thing for him was to write a book. Because of his book, he met with an African girl Anna. After graduation, he married with her and went to her hometown. He didn't find a job there and lived on the field Anna inherited from her parents. So, his whole life is just his wife's life. In this way, he felt that he was not safe and he was "far away from his nature ". In eighteen years' marriage, there was not one day that he wanted to stay. Finally, he gave up his marriage and divorced with Anna. After that, he went to visit his sister, in order to live a life totally belongs to him. However, he depended on his sister and idled away his life without doing anything except imaging. Later, he took part in underground movement under his sister's persuasion. The movement ended with failure. He then lived his life depending on his friends. He didn't find his ideal life, because he had no plans, no life goals and even no ability to practice. So, this, of course, is his destiny. To some extent, his lack of belongingness is caused by himself. Working takes up a long time in one's life, it is not simply to feed their stomach, most importantly, it provides people with a way to realize their self-value and life goals. This is the representation of a sense of belonging. However, Willie didn't realize it. Without true love with Anna, he still wants to love and be loved. In this sense, he focused his attention outside his family.

He had relationship with Jone, Pardita and some prostitutes, just for entertainment and satisfaction. His loved Pardita just because she was a white British woman; it was a kind of endeavor to increase his identity. He wanted to feel that he had some relationship with native people in this country and he was no longer an outsider; he was closely linked with this country and had some priority (Liu Wenyan, 2012: 46-49). However, outside family, he still can't find real happiness and real belongingness. He found that he was wrong; Anna was right. He then had to went to his sister's. From inside to outside and then went back, he drew a circle and he was still standing at the starting point.
The American famous psychologist Maslow proposed the Hierarchy of Needs (1943). He pointed out that the inner power of the development of an individual was motivation. Motivation is consist of different needs. When one need is fulfilled, the person seeks to fulfill the next one and so on. There are five needs, as can be seen in the following picture:

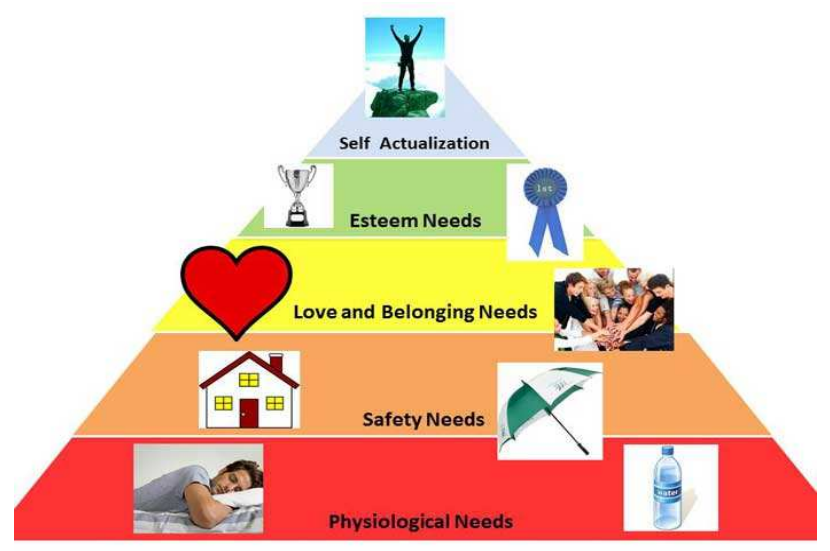

Figure 1. Maslow's Hierarchy of Needs (Form Google).

Needs can be classified into psychological needs, safety needs, love and belonging needs, esteem needs and self-actualization. The satisfaction of each need will influence people's personality. For Willie, whether inside his family or outside his family, the loss of love directly leads to the lack of belonging. In this regard, his esteem needs and self-actualization cannot be satisfied. In fact, happiness stays inside a family, not in the far-away outside. The environment inside a family is the purist. How can one find a sense of belonging outside family without finding one inside his/her home? Love is the nutrient for people's spiritual world. Love and be loved enables people to achieve their goals. For Willie, the loss of love is an important factor for his lack of $\mathrm{s}$ sense of belonging.

\section{Realistic Significance: The Current Sense of Belonging}

According to Spinoza (2010), all the things in the world are trying hard to maintain their existence. In this process, we are seeking for our sense of belonging, belongs to a family, a hometown, a school, etc. In China, More and more people take part in square dancing, men and women, old and young, not only to exercise but also to find s sense of belonging. Even belonging to a group, people won't feel lonely. Just like Willie, he participated in the underground movement, and at first, he knew that it was a wrong movement, but he still became a member of that group. People with different ages want to form their own circle, so that they can have the same topic to discuss, to be needed, to be understood and so on. This is a representation of a sense of belonging. Life is a process, and in each step, the sense of belonging can be different. It is a harbor of people's heart. 


\section{Conclusion}

Literature is the reflection of people's social life. A good work can be of great wisdom and benefit people for whole life. However, the wisdom of a book is little wisdom and the wisdom of life is the big one. The novels Half a Life and Magic Seeds are such kind books which provide us with the opportunity to think about the problem of a sense of belonging. They presented as an autobiography not only of Willie's life, but also of Naipaul's life. In these books, it seems that Naipaul belongs to at least three countries, but none of them give him the sense of home; he is indeed a rootless person (Wang Dan, 2013: 50). Willie is only one of the representatives among the those immigrants who try their best to claim for their identity and sense of belonging. So, it is of great significance of history. In this regard, this paper begins with the analysis of these two books in order to explore the protagonist's sense of belonging, and then, analyzes the reason for the protagonist's lack of belonging. Meanwhile, the paper analyzes the realistic significance in current society. A magic seed is a hope. Willie is trying hard to find a "home" for his soul, and we common people, also, should try to get our sense of belonging.

\section{References}

[1] Gao Z. C. A Probe into Naipaul's Thought of Novel[J]. Journal of Hainan Normal University(Social Science), 2005 (6): 94.

[2] Homi Bhabha. The Location of Culture[J]. Routledge, 2004.

[3] Kong C. The Growing Experience of Naipaul[J]. Foreign Literature Review, 2000 (2): 163.

[4] Liu W. Y. The Wheel of Desting of Naipaul's Works----On the Circle Structure and its Ethic Meaning in his Half a Life and Magic Seeds[J]. Journal of Lianyungang Teachers College, 2012 (1): 46-49.
[5] Maslow, A. H. A Theory of Human Motivation. Psychological Review[J], 1943(4): 370-96.

[6] Mei X. Y. Cultural Rootless---A Case Study of Naipaul's Immigrant Culture[D]. Northwest University, 2003.

[7] Naipaul, V. S., Half a Life[M]. New York: Alfred A. Knopf, 2001.

[8] Naipaul, V. S., Magic Seeds[M]. US: Alfred. A. Knopf.2005.

[9] Pan F. The Pursuit of Ego---An Explanation of Naipaul's Magic Seeds[J]. English and American Literary Studies, 2009 (10): 130-136.

[10] Spinoza, Ethics[M]. Translation by Parkinson. Everyman Classics. 1989.

[11] Said, E, Representations of the Intellectual [M]. Vintage.1994.

[12] Said E. Intellectuals in the post-Colonial World[M]. Salmagundi, 1986: 44-46.

[13] Wang S. L. An Analysis of V.S. Naipaul's Magic Seeds from the Perspective of Spatial Theory[J]. Foreign Language and Literature, 2010 (4): 7-9.

[14] Wang Y. R. The Pursuit of Belongingness_-On Naipaul's Novel Magic Seeds[J]. Journal of Language and Literature Studies, 2013 (10): 29-31.

[15] Wang D. Theme of Diaspora in V.S. Naipaul's Half a Life and Magic Seeds[D]. Harbin Normal University, 2013: 50.

[16] Xu Z. Q. The Half-life Journey of an "Outsider"-On Naipaul's Novel Magic Seeds[J]. Read, 2008 (7):97-101.

[17] http://en.wikipedia.org/wiki/Edward_Said

[18] http://www.simplypsychology.org/maslow.html

[19] http://en.wikipedia.org/wiki/V._S._Naipaul

[20] http://en.wikipedia.org/wiki/Half_a_Life_(novel)

[21] http://news.sohu.com/04/03/news146930304.shtml 